\title{
Project based Learning Application Experience in Engineering Courses: Database Case in the Professional Career of Systems Engineering
}

\author{
César Baluarte-Araya \\ Professional School of Systems Engineering \\ Universidad Nacional de San Agustín de Arequipa \\ Arequipa, Perú
}

\begin{abstract}
In many universities, training research is applied in courses as a basic element of research and fundamental in the professional training of every student, which result in strengthening and increasing knowledge about certain areas, as well as to achieve skills, competence, abilities and attitudes. The present work shows the formal application experience of the Project Based Learning (ABPr) methodology in Database Course (BD) at the Professional School of Systems Engineering (EPIS) of the National University of San Agustín (UNSA), Arequipa-Peru, accommodating the nature of the course being the theory taught by a teacher and laboratory practices by another teacher. The goal is to apply an active teaching strategy to an engineering training course. The methodology used is Project-Based Learning for a research project training for a real problem in an organization to be developed by each team in the semester, with deliverables that will be evaluated by grade scale and the formative research report assessed through the rubric; the input and feedback that the teacher makes of them serves for the improvement and experience in the training of the student. The results obtained show that the objectives in the training of students were achieved, as well as the development of the competencies related to the course, in addition that the application of ABPr gives good results for courses of an engineering career serving as feedback for the continuous improvement of this course and experience for the implementation of $\mathrm{ABPr}$ in other curriculum courses. Concluding that formative research as a pillar of a basic level of research initiation is given in a cross-cutting way in the curriculum courses, that the active teaching strategies properly planned and properly applied to each reality allow to achieve the desired results such as: increase knowledge of the area, strengthen skills, abilities, attitudes as the case of the present.
\end{abstract}

Keywords-Project based learning; formative research; competences; skills; formative research report

\section{INTRODUCTION}

Student training at the university level, particularly in the area of engineering, has in recent years been treated in addition to conforming to international standards such as [1] and other Spanish-speaking standards such as [2],[3] which accredit curricula university is to include in courses of curricular plans the formative research that aims to enable graduates to achieve in their vocational training to base an adequate level of research within their skills to develop knowledge and apply it to change the reality for the good of the society to which they are due; thus, the teacher by including in the course syllable the training research can use teaching strategies [4], [5] appropriate to the nature of the course to achieve the objectives and competences.

With previous experience in the Professional School of Systems Engineering [6], of the National University of San Agustín [7], Arequipa - Peru, in the course of Writing Articles and Research Reports (RAII) taught in the III semester since the academic year 2014 in which the preparation of poster and documentary research article is available as deliverables, thus having a first level of formative research undergoing specialty and of developing in the student soft skills, abilities; the development of other skills and competencies needed to achieve a higher level of research is determined in the database course taught in the fifth semester of the Curriculum to apply the Project-Based Learning (ABPr) methodology for the database design and as another result the preparation of the Formative Research Report; that admits in some way its evaluation and validate what has been done, and to strengthen soft skills and abilities in the use of techniques and tools.

UNSA decided to include in the syllable structure of the courses of the Curriculum Plan of the Professional Schools training research to address the shortcomings of students in knowledge, skills and abilities, making the teacher use the best teaching strategies in teaching learning the institutional educational model by competencies; is so for the Database course the Project-Based Learning methodology is applied to the project of designing a database of a real problem of an organization and that through the software developed using the methodologies, techniques and tools the student manages to validate the elaborate design; delivering the training research report based on the template used that includes items such as: executive summary, introduction, objectives, theoretical framework, methodology, results, conclusions, recommendations, references, annexes, self-assessment; which will be evaluated with the relevant rubric.

The objective pursued is to apply the ABPr for the first time formally to the System Engineering Professional Career Database course in solving various real-world problems by the trained work teams; managing to produce reports by the deliverables of established laboratory sessions, the training research report, to increase their skills and abilities to propose solutions in changing environments, interact in situations, take 
decisions, work as a team; as it refers [8] in this new knowledge society.

The research is descriptive level and the methodology used for development is based on the phases of problem solving, of the scientific method [9] who states that the student allows to develop skills; for the present work adapting and expanding others; the survey technique and its instrument are also applied to the questionnaire to obtain the data, systematize it, analyze the results to reach the relevant conclusions pursued by the research.

Achieving as results that the students in their working group applying the ABPr developed the project of designing a $\mathrm{BD}$ of a problem of reality, which to be validated develops the software application thus validating the design by complying with the user requirements and have the necessary functionality. Thus also students have the perception and recognize having applied and achieved perfecting their skills, abilities, attitudes and valuing the result achieved in the project worked in the course.

Conclusions are reached such as that the Project-Based Learning methodology is ideal for enhancing autonomous learning, developing skills, abilities and achieving good performance in students; recognizing that what has been achieved in the real-life problem project serves for their future professional performance in the sectors where it will perform; it also reinforces the process of research training which takes place in a cross-cutting way in this course and of being able to take place in others of the Curriculum Plan.

The paper is organized in following sections; Section II of Related Works - Context of Experience, Section III deals with the Design of the Formative Research Project, Section IV shows the Method of Work that shows the stages for the development of the project, Section V shows the perceptions that students have of the ABPr strategy and of the Experiences left by the Development of the Database course with this strategy, Section VI shows the results of the Evaluation of the Research Report Formative, Section VII shows the Lessons Learned from Development and that leads to continuous improvement, in Section VIII the Discussion that is made is touched, that others investigated or worked and the result obtained that contributes to the integral training of the student, Section IX presents the conclusions of the work, Section X shows the future work that could be enhanced, Section XI shows the respective appreciation, and Section XII shows the respective References.

\section{RELATED WORKS: CONTEXT OF EXPERIENCE}

\section{A. Formative Research}

In this topic [10] addresses how the problem of the teaching-research relationship contemplates the role that research can play in learning the same research and knowledge. Thus he considers that "formative research" has to do with the concept of "training", of shaping, of structuring something throughout a process. This training, for our case, refers to students who are prepared, through the activities developed, to understand and advance scientific research in their training.
It focuses on the learning strategy by discovery and construction of knowledge, where the student is the center of the process, starting from a problem seeks, finds, examines sources of environments or similar success stories, related writings, collecting the data, organizing it, classifying it, ordering it, interpreting the results until we get statements of proposals or solutions. Interesting to mention that teachers use methods, practices for formative research with students from undergraduate work, theoretical essay, in research work with the teacher when working rigorously in advising research. In some way it refers [11] that learning is participatory, studentcentered and the use of active methodologies used in the area of accounting by quoting Activity-Based Learning and ProjectBased Learning.

Thus also [12] contemplates in the sub-process: Management of Formative Research where they establish mechanisms to integrate the research process into the teachinglearning process; where the task of Developing Didactic Strategies in the teaching-learning process designs the methodological mechanisms where problem-based learning, case study, portfolio, without neglecting others such as learning based on projects would narrow down as well.

For his part [13] in his study he analyzes the role of formative research in the development of undergraduate scientific competences by driving scenarios that drive research processes; and to assess the perception of students of their contribution and impact of the vocational training process on the development of their research skills; showing the quantitative analysis of the at-attitudinal profile resulting from the main indicators on the scale of attitudes presented: There should be more incentives and incentives to promote research with 69.2 points; I believe that research is a very important tool for generating new knowledge with 62.5 points; I think my program should re-evaluate how it guides the research with 50.0 points.

Since 2014, exists the first experience in EPIS to initiate the formative research reflected in the work of [14] with reference from results of previous works [15-16] in demonstrating and validating the achievement of students in developing articles of and in addition to reaching skills and developing soft skills.

\section{B. Project based Learning}

As it was discussed in [14] referring to [1] that says ..."Our future graduates should be able to work in a global environment in multidisciplinary teams, solving constantly changing problems. In addition to much of what students have learned (technologies, software, methodologies, programming languages, etc.) will have changed by the time they graduate."; there is an expectation that students will be warmed up in addition to the technical knowledge that they are from the curriculum, with soft and professional skills in their training as engineers.

For the [17] ABPr, "It is a learning methodology in which students are asked, in small groups, to plan, create and evaluate a project that responds to the needs posed in a given situation."

There are many experiences of universities in the world that use active methodologies, such as to cite Spanish, [10], [11], [12] where the focus is on the student, acquisition of new 
knowledge, participatory teamwork and collaborative, concrete results of the problem of reality, so also for [18] is learning to solve complex problems of applying to real situations the knowledge and skills acquired in their training through the project planning, designing, carrying out a set of activities in a given time; for [19] $\mathrm{ABPr}$ is relevant to students' work in learning essential knowledge and skills in a real project in realworld contexts in the Software Project Workshop engineering course, where learning is directed to the skills development and evaluation is with respect to performance in effective work. However, some teachers employ a scenario of a fictional project that can take place in the professional exercise [20] where the student is given the information of the organization showing problems and other aspects, enhancing the autonomous and increase academic performance; collecting by survey opinions on the methodology and academic results of the course.

The ABPr has characteristics that we will consider summarizing those of [4]:

- Affinity with real situations, in the world of work

- Practical relevance, theoretical-practical exercise of job insertion and professional development

- Student-oriented approach to their interests and needs

- Action-oriented approach, autonomous concrete actions, both intellectual and practical

- Product-oriented approach, obtaining relevant results subject to valuation and criticism

- Process-oriented approach, Learn to learn, learn how to do and learn to act.

- Self-organization: Goal determination, planning, realization and control are decided and carried out by the students themselves.

- Collective realization: Students learn and work together in the realization and development of the project.

- Interdisciplinary character: Through the realization of the project, different areas of knowledge, subjects and specialties can be combined.

\section{Learning Assessment}

The assessment of learning when applying ABPr in the teaching learning process of the subject treated can be carried out through instruments that adapt to each reality studied and to be resolved, for the case the rubric [21-23] is used through the establishment of criteria and levels of achievement to assess knowledge, learning achieved, achievement of skills, using a scale of qualification, making students known at the beginning of the course their content and description of rubric.

It is important to feedback from students' learning process as they worked [23] by comparing feedback to evaluate with rubrics to their experimental group to see if it facilitated selfreflection, self-assessment by students and improve learning outcomes versus traditional feedback; reached conclusions where feedback is effective if it focuses on learning and makes it easier for the student to develop self-regulation skills, selfsensing and found significant differences in all forms of assessment in the experimental group. Also finding differences between the different forms of evaluation and the learning results obtained.

If constructive guidance is taken into account in the curricular proposals [24] consider the relationship between evaluation methods using as criteria the desired effects of the evaluation, reaching the current didactic syllalists adapting to reality or nature of each course and the activities that are programmed to achieve learning; with the intention of giving students the opportunity to continue learning, this requires an evaluation as part of an order generating learning experiences for the actors.

In addition [25] from the competency approach, it sees the evaluation aimed at evaluating students' performance against an activity or problem of their profession being referenced in evidence and indicators, this objective and consistent assessment of the activities; also allowing to evaluate the competencies related to the application, synthesis, criticism reflecting the lesser or greater mastery of competence on the part of the student.

\section{DESIGN OF THE FORMATIVE RESEARCH PROJECT}

For the development of the project, aspects were considered to be relevant and to deal with a problem of reality where the student expands the knowledge and applies the methodologies, techniques and tools related to the course of his curricular plan, which in addition to research activities allow the student to produce reports with defined structure and be evaluated.

Database is a practical theoretical course developed in the shared chair of a professor in theory and a professor in laboratory practices. The work teams develop the design project of a BD and developing the software application as a result that validate design by meeting requirements and having functionality.

For the case there are scenarios of the various real organizations both business and governmental, where the student assumes the specific technical roles in the organization of the project, having to relieve the data and information of the problem main subject of the project.

\section{A. The Project}

The project to be developed has as features:

- Be a problem of a real organization

- The team of 2 students

- Each team's projects will be recorded

- Will be developed throughout the academic semester.

Fig. 1 shows the record of the formative research projects of the course. 


\begin{tabular}{|c|c|c|c|c|c|c|}
\hline & \multicolumn{2}{|c|}{ National University of San Agustín of Arequipa } & & & & \\
\hline & \multicolumn{2}{|c|}{ Faculty of Production Engineering and Services } & & & & \\
\hline & \multicolumn{2}{|c|}{ Professional School of Systems Engineering } & & & & \\
\hline & & & \multicolumn{3}{|c|}{ FORMATIVE RESEARCH PROJECTS - SEMESTER 2019 A } & \\
\hline \multirow{2}{*}{\multicolumn{2}{|c|}{ Course: Database }} & & \multicolumn{2}{|c|}{ Professor: PhD Eng. César Baluarte Araya } & & \\
\hline & & & \multicolumn{2}{|c|}{ Chief of Practice: Eng. Christian Portugal Zambrano } & & \\
\hline & General Goal & $\begin{array}{l}\text { Design the Database of a } \\
\text { Problem of the reality of } \\
\text { an organization. }\end{array}$ & & & & \\
\hline & Specific Objectives & $\begin{array}{l}\text { Modeling the problem of } \\
\text { an organization's reality. } \\
\text { Identify, research and } \\
\text { propose a solution using } \\
\text { methodologies, } \\
\text { techniques and tools. }\end{array}$ & $\begin{array}{l}\text { Design the Reality Problem } \\
\text { Database that meets the } \\
\text { system requirements for } \\
\text { your implementation. }\end{array}$ & $\begin{array}{l}\text { Use modern tools and } \\
\text { information technologies, } \\
\text { selecting and adapting the } \\
\text { most appropriate tools and } \\
\text { technologies. }\end{array}$ & & \\
\hline No. & Research Lines & Project Name & General Goal & $\begin{array}{c}\text { Last Name and Investigator } \\
\text { Names }\end{array}$ & Date Start & End Date \\
\hline 1 & $\begin{array}{l}\text { Technological } \\
\text { Innovation }\end{array}$ & $\begin{array}{l}\text { Clothing Custom } \\
\text { Database Design }\end{array}$ & $\begin{array}{l}\text { Design the Database of the } \\
\text { Apparel Commissions } \\
\text { Required by Customers. }\end{array}$ & $\begin{array}{l}\text { Silloca Castro Raquel } \\
\text { Stephanie }\end{array}$ & 20190318 & 20190712 \\
\hline
\end{tabular}

Fig 1. Formative Research Projects. Source: Own Elaboration.

\section{B. Project Theme Assignment}

In the development of the laboratory sessions of the database course from 2014 the sessions of a project to be developed during the semester by groups consisting of 2 students, according to the considerations for this: disposition of communication, meeting, working hours for the project and study of other courses of the team members, compatibility of personal interrelationship; giving very good results. Having that precedent in this experience it was decided to continue with the assignment of random topics to the trained groups, who go to the organizations to request to carry out the project of the assigned topic, considering that if in the organization they pose another issue of a problem to work they can do so.

\section{Tracking}

As the semester progresses, the feedback of the results of the deliverable is made in each laboratory session, which leads the student to make the relevant modifications that will serve it for the following future sessions due to the nature of the project in the course.

The teacher plays the role of counselor by giving suggestions, guiding and helping the team, students develop the project as independently as possible.

\section{Evaluation}

The evaluation at the laboratory sessions from 2008 to 2017 was considered to be carried out of the respective deliverable according to the checklist criterion established for adequate compliance with the result to be delivered.

For the year 2019 in the new competency curriculum the evaluation for the engineering area is adopted as the main instrument for evaluating the course's competencies; the topic's rating scale or development checklist for lab deliverables, which are stored in a virtual classroom repository resembling a portfolio by deliverable, is used in this course; and the rubric for the evaluation of the final formative research report.
The theoretical development of the course was determined to use the rubric evaluation strategy that makes it better to achieve a better result and achieve the objectives. What is stated by [21] is a good criterion of carrying out the learning and evaluation tasks in the student-teacher relationship, and by [23] that makes it easier for the student to be consistent with how far his learnings go and what is the maximum desirable level; in order to achieve:

- Set achievable goals, conducting a Real BD Design, an application that validates the $\mathrm{BD}$, a formative research report.

- Develop a project using ABPr based on a methodology established for the case.

- Carry on the part of the teacher monitoring and feedback through the deliverables and their assessments for continuous improvement.

- Increase the interpersonal and social relationships of the participants of the task team.

- Manage the time for the execution of deliverables.

\section{METHOD OF WORK}

\section{A. Conceptual Design}

There are for the development of the project experimental studies such as that of [08] [19] [20] that serve as a reference and generate something proper to the course of $\mathrm{BD}$ at the university level in the professional career of Systems Engineering.

The purpose is for the student to search, research, review similar situations, review related literature, collect, organize, interpret data and list alternatives for solving a real problem of reality in an organization, but then the ABPr strategy that targets the $\mathrm{BD}$ course is used to strengthen and discover greater knowledge and also the development of skills, abilities, and assessment of its results. 
The research developed is of descriptive level and the methodology used for development is based on the phases of problem solving, based on the scientific method, which allows the student to develop skills such as: delimit a problem, formulate solution hypotheses, design experiments, observe, measure, gather information and data, analyze them, draw conclusions; for the present work adapting and expanding others; the survey technique and its instrument of the questionnaire are also applied to obtain the perception data, systematize it, analyze the results to reach the relevant conclusions pursued by the research, and be taken into account for continuous improvement.

The stages defined for project development are shown below:

1) Starting point

Main theme

- Design and implementation of a database

- Initial Question

- With the knowledge gained and complemented by the database, it will be possible to design and implement a database in a real-world situation?

2) Collaborative Team Training

- Team / group of 2 people.

3) Definition of the Final Product

Product to be developed.

- Design and implement the database of a module or subsystem of information of a real problem of a real organization.

What to know (learning objectives)

- Perform conceptual modeling of the database

- Perform the logical design of the database

- Perform the physical design of the database

- Perform application development to validate the database.

4) Organization and Planning

Role assignment

- Team members' roles will be rotating for each evaluable session, considering:

$$
\begin{array}{ll}
\circ & \text { Project Manager } \\
\bigcirc & \text { Project Analyst } \\
\bigcirc & \text { Application Scheduler } \\
\bigcirc & \text { Defining tasks and times }
\end{array}
$$

- Planning

- Coordination

- Control.
5) Search and Collection of Information - in the Organization

- Review of objectives.

- Recovery of Previous Knowledge, course material, bibliography, references in research database (Scopus, Web of Science, Google Academics, etc.).

- Introduction of new concepts.

- Search for information (primary sources, research thesis, success stories, other sources).

6) Analysis and Synthesis

- Sharing, sharing information; organization of information and prepare it using tools appropriate to the project.

- Contrast of ideas, debate; analysis of the situation of the problem to be solved.

- Troubleshooting; according to the stages of database development in organizations.

- Decision-making; to perform the following activities.

7) Design

- Conceptual Design

- Logical Design

- Physical design.

8) Development of the Application

Demonstrating the proper design of the database; using development tools, and demonstrating their applicability in solving the problem.

9) Project Presentation

- Present the results of the project or its stages

- Review and Evaluation of the project or its stages.

10)Preparation of the formative research report

Prepare the report in accordance with the drafting template.

11)Evaluation of the formative research report

- The teacher evaluates the report using the rubric.

- Includes general self-assessment of the work team.

Techniques and Instruments to Use

A. Techniques and Instruments

- $\quad$ Project-Based Learning

- Project development - project of the course, - in stages within the development of the course in database laboratories.

- Survey

- Questionnaire - appreciation on the part of students. 
- Project Development - course project, which will be completed in stages during the development of laboratory practices, which are evaluated.

B. Evidence

- Digital files, lab work.

- Moodle, as a repository for course work.

- Portfolio, which will initially be assembled from the project outline, laboratory guides, data dictionary, the work performed considered as deliverables.

Tools

The tools to use are:

- Computer

- Software

- Operating System; Linux, Windows or other

- Programming language; Java, PHP or other

- Database Management System, MySQL, Postgres, or other.

- Application tools

- Suite Office

- Data Dictionary

- TOAD.

- Other

- Standards for BD Project - Development - Offprint UNSA 2019.

\section{B. Participants}

The BD course of the Systems Engineering career is taught in the fifth semester (3rd year), has 6 hours per week, 4 theoretical and 2 in laboratory, the semester has 17 weeks; participating in the evaluation of the Formative Research Report 74 students being the sample size; the theory of the course was in charge of a teacher and the laboratory practices in charge of another teacher forming 4 groups.

\section{Data Analysis Technique}

The data analysis technique was through the processing of the assessment of deliverables, the evaluation of the final formative research report, as well as the application of the questionnaire instrument to the sample to collect data from the survey of statistical, the data were systematized in the EXCEL electronic spreadsheet, analyzing the results obtained as statistics: averages and frequencies, charts, tables and tables.

\section{Instruments}

The use of the instruments is envisaged:

- Laboratory Guides

- Training research report template

- Evaluation rubrics

- BD course evaluation matrix.

\section{E. Techniques}

As evaluation techniques:

- The rubric

- The Grading Scale.

\section{F. Deliverables and Assessments}

From the laboratory sessions the deliverables were determined, which are developed and delivered by each team whose evaluation leads to a respective qualification and continuous and immediate feedback that favors the learning process and the skills development.

Table I shows the deliverables of the course lab sessions in the academic semester.

TABLE I. LIST OF DELIVERABLES FOR EVALUATION WITH ABPR METHODOLOGY

\begin{tabular}{|c|c|}
\hline Table I & Descriotión Deliverable \\
\hline Session 1 & $\begin{array}{l}\text { Take the actions to take a tour of the SGBD Access to } \\
\text { visualize its functionality and to contemplate the concepts } \\
\text { that are immersed in the. } \\
\text { Carry out the complementary work of viewing the videos of } \\
\text { the Access Basico } 2010 \text { Course. } \\
\text { Designing a company's Orders BD by considering the tables } \\
\text { and data given from: Customer, Seller, Zone, Order, Item. } \\
\text { Prepare the deliverable report. }\end{array}$ \\
\hline Sesion 2 & $\begin{array}{l}\text { Develop the Data Dictionary of a Module or Information } \\
\text { Subsystem of a real company }\end{array}$ \\
\hline Sesion 3 & $\begin{array}{l}\text { Model a database from the work or case study or topic } \\
\text { assigned and worked on the practice of data dictionary using } \\
\text { an automation tool to help model data to be performed. } \\
\text { Developing the Relationship Entity Model. }\end{array}$ \\
\hline Sesion 4 & $\begin{array}{l}\text { Develop the Conceptual Schema from the use of an } \\
\text { automation tool to aid data modeling. } \\
\text { Use the TOAD tool to model data. }\end{array}$ \\
\hline Sesion 5 & Developing data modeling using standardization. \\
\hline Sesion 6 & $\begin{array}{l}\text { Work in the working environment of the MySQL database } \\
\text { management system. } \\
\text { Create the database of your lab job topic in the MySQL } \\
\text { database management system. } \\
\text { Establish the connection to the MySQL database to work } \\
\text { with the JAVA programming language. }\end{array}$ \\
\hline Sesion 7 & $\begin{array}{l}\text { Develop data upload programs to the MySQL database. } \\
\text { Establish the connection to the database to then manipulate } \\
\text { the data with the application programs. }\end{array}$ \\
\hline Sesion 8 & $\begin{array}{l}\text { Manipulating data using the SQL functions of a MySQL } \\
\text { database. } \\
\text { Handling the added functions. } \\
\text { Database View Management. }\end{array}$ \\
\hline Sesion 9 & $\begin{array}{l}\text { Manipulating data using SQL triggers from a MySQL } \\
\text { database. } \\
\text { Handling stored procedures. }\end{array}$ \\
\hline
\end{tabular}

Source: Own elaboration. 
The structure of the Formative Research report is shown below:

Cover

Index

Executive summary

I. Introduction

II. Objectives

1. Overall objective

2. Specific objectives

III. Theoretical Framework

IV. Methodology

V. Results

VI. Conclusions

VII. Recommendations

VIII. References (IEEE, APA)

Annexes

Self-assessment

\section{Perceptions, Data base Course DeVelopment EXPERIENCIES}

The following perceptions and experiences are presented as a result of applying $\mathrm{ABPr}$ in the $\mathrm{BD}$ course project:

\section{A. Perceptions}

- It is perceived that the student assimilates in each deliverable what at the beginning of the course had as knowledge, the objective that is pursued and to know what in the future will help in subsequent courses of the career.

- There is a perception that there is motivation to carry out a project of a real case or problem of an organization, which is systematically developed until the final product is obtained.

- Having feedback on the various partial deliverables by the review and observations made by the teacher for the correction, improvement and continuation of the project.

- The student is perceived to reinforce the skills and abilities by assessing the level achieved that allows to:

- Properly draft the formative research report

- Conduct adequate documentary research of the theoretical framework complementary to that provided to increase its knowledge.

- It is perceived that at the end of the course the student achieves the competencies.

- The objectives of the course have been achieved.

\section{B. Experiencies}

You have the following experiences of the developed course:
- For the first time, Project-Based Learning is formally and systematically used for an engineering specialty training course.

- Use the fundamental phases of scientific research with adaptation to Project-Based Learning that is reflected in the final report of formative research prepared by students.

- The skills and abilities achieved by the student in the RAII course are reinforced by being contemplated in the activities raised in the $\mathrm{BD}$ course project and through formative research.

- The time experienced by $38 \%$ of students having contact for the first time with reality in an organization like the company, which breaks the taboo of "what it will be".

- Designing practice guides that help students have a base support to develop the required deliverable.

- The use of the methodologies, techniques and tools necessary for the development of each project deliverable.

- Use the data dictionary as a fundamental tool for BD design as it supports the development of other project activities.

\section{RESULTS}

The results of the Evaluation of the Training Research Report (EIIF) carried out with the corresponding rubric of the BD course are shown below.

$\mathrm{BD}$ is a course where the student ultimately drafts a formative research report under a previously defined scheme and used for the purpose. This allows previously exposed to developing skills in writing, communication, among others.

Fig. 2 shows the number of students who were evaluated according to the criteria, their level and rating scale according to the established rubric.

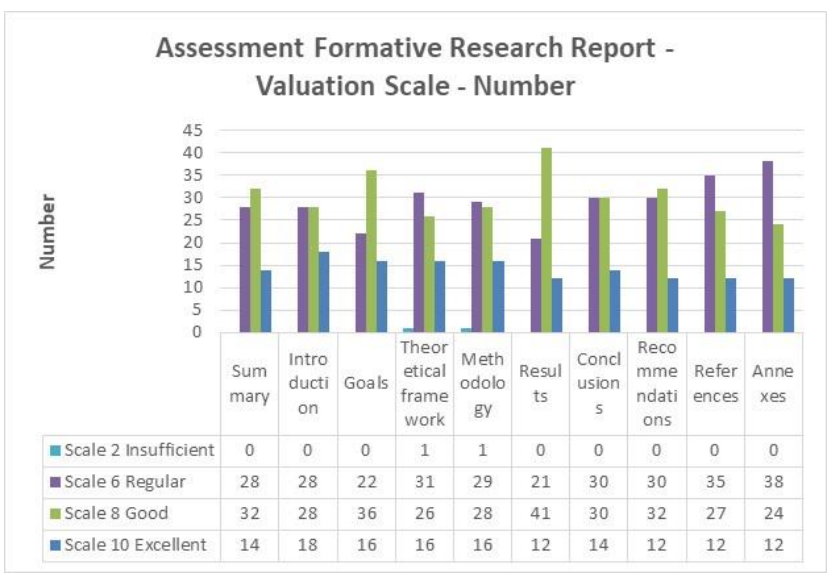

Fig 2. AFRR - Valuation Scale - Number. Source: Own elaboration. 
Fig. 3 shows the percentages of students who were evaluated under the same parameters, having the following interpretations:

- Students pass the assessment that is reflected from the regular level towards the excellent, which manifests to prepare the training research report in an appropriate way.

For the following interpretations it is considered to the Good and Excellent levels of the rating scale.

- The Summary criterion shows that $62.16 \%$ manage to develop it according to the structure normally used in its elaboration as: the topic to be investigated, objectives, results, conclusions and recommendations.

- By the Introduction criterion, $62.16 \%$ should clearly and punctually address the subject to be investigated, the objective, justification, benefits or contributions.

- The Objectives criterion has $70.27 \%$ to set and draft the overall objective and specific objectives in a clear and coherent way of the research topic.

- By the Theoretical Framework criterion it is given that $56.76 \%$ give a detailed description of each of the theoretical elements that were used directly in the development of research as: concepts, techniques, tools, research work related cases, success stories.

- The Methodology criterion shows that $59.46 \%$ reflect in addition to the type of research, method of information collection; contemplates the stages or phases used in the development of the project; clearly explaining each of them.

- The Results criterion has $71.62 \%$ including the results obtained from the project; to cite: Conceptual Design of the BD, Logical Design of the BD, Physical Design of the DB, Prototype of the software application that shows the implementation and operation of the DB.

- The Conclusions criterion shows that $59.46 \%$ draw clearly and in a timely manner the conclusions reached in the project that meet the objective set.

- The Recommendations criterion shows that 59.46\% clearly and promptly draw the recommendations derived from the project results and based on the conclusions.

- By the References criterion, $52.70 \%$ have to draw up the list of references used in the report according to the specified standard or style.

- The Annexes criterion shows that $48.65 \%$ include other diagrams not included in the report body such as: tables, graphs, infographics, print screens; estimated expediently.

Based on the above, it can be determined that an average of $60.27 \%$ is achieved by students in an appropriate manner of the Formative Research Report; which is very promising as $\mathrm{ABPr}$ application experience for an engineering specialty course.

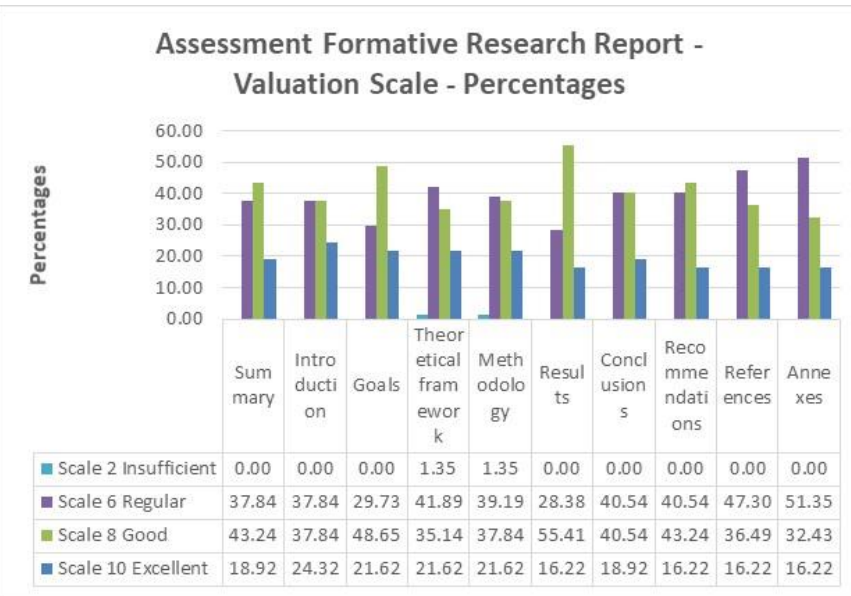

Fig 3. AFRR - Valuation Scale - Percentages. Source: Own elaboration.

\section{LESSONS LEARNED}

The development of the $\mathrm{ABPr}$ database course leaves lessons learned that leads to continuous improvement resulting in the professional training of students, namely:

- Laboratory Practice Guides

It is confirmed that updating the topics allows the student to have a broad spectrum of information and knowledge to work on them.

- From the assessment

The rubric is used as an evaluation tool for both the theoretical and laboratory parts relating to the formative research report; which may have adjustments for the development of the next course.

\section{DISCUSSION}

Based on the engineering concept of [8] ..."Engineering is the conceptualization, design, construction and management of projects and products aimed at solving a need of society or the environment". Thus the engineer must solve problems, for this it must have ingenuity, creativity, knowledge, skills, skills, analytical capacity, synthesis, and decision-making, among other aspects.

With the focus of skills training much has been written by authors such as INACAP [4], ITESCA [5] and considering that learning outcomes should be obtained using appropriate methodologies [18], from a revision of the ABPr model by [26] and [27] which reflects on the mention that it is being promoted as teaching methodologies in the work of projects, stating that it is understood by an appropriate context, as selected according to knowledge-related learning objectives to be built, conceived and applied a research process; which is also geared to incentivizing the culture of research as in many universities in Peru has been carried out in greater depth since the new University Law of 2014, based on it it has to be that many university educational institutions adopt changes that lead to a comprehensive training of their students; so through the norms of UNSA in research training based on transversal formative research in curriculum courses, formative research is taken in the syllables of the courses; taking, for example, that 
to date it has obtained results by having at the end of 2019, five graduates in the EPIS with the modality of scientific article published in indexed journal; being the first university at the Peru level recognized by SUNEDU (National Department of Education); this stems from the proper use of teaching strategies arising from social, economic, cultural, technological changes which require that the capital or human resource that is inserted into organizations be formed according to what the society sues, and how students carry out a project; BD case; in a certain time to solve a problem of reality in an organization or face an investigative task with proper planning, design, development, carrying out a set of activities, based on the progress and application of learning and effective use of resources.

This research work has succeeded in executing practical applications in the development of the BD course that assists in the integral training of the student in the field of knowledge, skills, abilities, reporting strategies, processing data and information, motivation to learn and achieve skills, achieving an adequate level of proficiency that allows for better development and advance in the levels of approval in your professional training; which also serves for job performance in the future.

\section{CONCLUSIONS}

The following conclusions have been reached:

- Project-based Learning as an active methodology enhances autonomous learning by increasing knowledge, understanding topics, allowing to apply the knowledge acquired in class, allowing to strengthen the development of skills and abilities, as well as better academic performance, motivation and teamwork of students.

- The training process in formative research takes a crosssectional course in the courses following the RAII course involved in the Curriculum Plan, as is the case with the Database course.

- Applying appropriate teaching strategies in other courses culminating in the thesis and thesis seminar essay project courses, allows to reach students with the highest level of research for undergraduate.

- Student recognition that what has been achieved in the development of the real life project in an organization serves for their professional performance in the sectors where it will take place in the future.

- Project development must be planned in great detail to achieve the desired results.

- Students reached the course competencies that contribute to their career competencies.

- The evaluation of the formative research report has made it possible to validate the achievements and gaps in the monitoring or tracing that is carried out to each task team that will allow the appropriate adjustments to be made for a better project development in the future course.

\section{FUTURE WORKS}

- Conduct comparative research of the results obtained from applying ABPr in engineering specialty courses.

- Conduct a research of the tranverexited of applying active teaching strategies in the training of the student.

- Reiterate conduct training research in other courses for the development of other skills, abilities or competencies in students of the professional career; to complement their vocational training.

\section{ACKNOWLEDGEMENT}

Our thanks to the National University of San Agustín of Arequipa for allowing and supporting the development of Formative Research that is of the interest of students.

\section{REFERENCES}

[1] ABET. Why ABET Accreditation Matters. https://www.abet.org /accreditation/what-is-accreditation/why-abet-accreditation-matters/. Ultimo acceso diciembre 2020.

[2] ANECA, Agencia Nacional de Evaluación de la Calidad y Acreditación, España. www.aneca.es

[3] CNA, Consejo Nacional de Acreditación, Colombia. https://www.cna.gov.co/1741/articles-186359 pregrado 2013.pdf

[4] Subdirección de Currículum y Evaluación, Dirección de Desarrollo Académico, Vicerrectoría Académica de Pregrado, Universidad Tecnológica de Chile INACAP. (2017). Manual de Estrategias Didácticas: Orientaciones para su selección. Santiago, Chile: Ediciones INACAP.

[5] Rodriguez Cruz, Reyna, Compendio de estrategias bajo el enfoque por competencias, Instituto Tecnológico de Sonora ITESCA, México, 2007. http://www.itesca.edu.mx/documentos/desarrollo_academico/compendio _de_estrategias_didacticas.pdf.

[6] Escuela Profesional de Ingeniería de Sistemas. http://www. episunsa.edu.pe.

[7] Universidad Nacional de San Agustín de Arequipa. http://www .unsa.edu.pe.

[8] Rodríguez-Sandoval, Eduardo; Vargas-Solano, Édgar Mauricio; LunaCortés, Janeth, Evaluación de la estrategia "aprendizaje basado en proyectos", Educación y Educadores, vol. 13, núm. 1, abril, 2010, pp. 13-25 Universidad de La Sabana, Cundinamarca, Colombia.

[9] GARZA-RIVERA, RG. El rol de la física en la formación del ingeniero. Ingenierías, 2001, vol. IV, No. 13, pp. 48-54.

[10] Restrepo Gómez, Bernardo, INVESTIGACIÓN FORMATIVA E INVESTIGACIÓN PRODUCTIVA DE CONOCIMIENTO EN LA UNIVERSIDAD, Nómadas (Col), núm. 18, mayo, 2003, pp. 195-202, Universidad Central, Bogotá, Colombia.

[11] Carrasco Gallego, Amalia; Donoso Anes, José Antonio; Duarte-Atoche, Teresa; Hernández Borreguero, José Julián; López Gavira, Rosario; Diseño y validación de un cuestionario que mide la percepción de efectividad del uso de metodologías de participación activa (CEMPA). El caso del Aprendizaje Basado en Proyectos (ABPrj) en la docencia de la contabilidad; INNOVAR. Revista de Ciencias Administrativas y Sociales, vol. 25, núm. 58, octubre diciembre, 2015, pp. 143-158; Universidad Nacional de Colombia, Bogotá, Colombia.

[12] Mejía Murillo, Carmen, Manual de Procesos de Investigación Formativa, Universidad Herminio Valdizán, Perú, 2016.

[13] Pinto Santos, Alba, Cortés Peña, Omar, ¿Qué Piensan los Estudiantes Universitarios Frente a la Formacion Investigativa?, REDU. Revista de Docencia Universitaria, 2017, 15(2), 57-75.

[14] Baluarte Araya, César., Vidal Duarte, Elizabeth, Castro Gutierrez, Eveling, Validación de las Habilidades Blandas en los cursos de la Currícula de la Escuela Profesional de Ingeniería de Sistemas-UNSA, 16th LACCEI International Multi-Conference for Engineering, Education, and Technology: "Innovation in Education and Inclusion", 19-21 July 2018, Lima, Perú. Digital Object Identifier (DOI): 
http://dx.doi.org/10.18687/LACCEI2018.1.1.97 ISBN: 978-0-99934431-6 ISSN: 2414-6390.

[15] Baluarte, C., Vidal, E., Delgado, L., Castro, E.; Integrando Habilidades Blandas: Redacción, Comunicación y Ética en la Currícula de la Escuela Profesional de Ingeniería de Sistemas - UNSA; $15^{\text {th }}$ LACCEI International Multi-Conference for Engineering, Education, and Technology: "Global Partnerships for Development and Engineering Education", 19-21 July 2017, Boca Raton Fl, United States. Digital Object Identifier (DOI): http://dx.doi.org/10.18687/LACCEI2017. 1.1.141 ISBN: 978-0-9993443-0-9 ISSN: 2414-6390.

[16] Castro, E., Vidal, E., Baluarte, C., Integrando la Comprensión de la Responsabilidad Ética y Profesional en una Carrera de Ingeniería: Experiencia y Lecciones Aprendidas, 14th LACCEI International MultiConference for Engineering, Education, and Technology: "Engineering Innovations for Global Sustainability”, 20-22 July 2016, San José, Costa Rica, RP139.

[17] Universidad Politécnica de Madrid. (2008). Aprendizaje orientado a proyectos. Recuperado de: http://innovacioneducativa.upm.es/guias/AP _PROYECTOS.pdf

[18] Dirección de Desarrollo Curricular y Docente, Universidad de La Frontera, Manual de orientaciones: Estrategias Metodológicas de Enseñanza y Evaluación de Resultados de Aprendizaje, Chile, 2018.

[19] Marco A. Villalobos-Abarca, Marco, Herrera-Acuña, Raúl A. Ramírez, Ibar G. Cruz, Ximena C., Aprendizaje Basado en Proyectos Reales Aplicado a la Formación del Ingeniero de Software, Formación Universitaria, Vol. 11(3), 97-112 (2018) http://dx.doi.org/10.4067/S0718-50062018000300097, UTA, Chile.

[20] Rodríguez Andara, Alejandro, Río Belver, Rosa, Larrañaga Lesaka, José María; Aprendizaje Basada en Proyecto (PBL), descripción de una experiencia desarrollada en aula universitaria y sugerencias para optimizar resultados, Universidad del País Vasco, España.

[21] Octaedro, Rúbricas para la evaluación de competencias, España, 2013.

[22] Cano, Elena, Las rubricas como instrumento de evaluación de competencias en educación superior uso o abuso, Profesorado, VOL. 19, $\mathrm{N}^{\circ} 2$ (mayo-agosto 2015), Universidad de Barcelona, España.

[23] Sáiz Manzanares, Maria Consuelo y Bol Arreba, Alfredo; Aprendizaje basado en la evaluación mediante rúbricas en educación superior, Elsevier, Suma Psicologica, SUMA PSICOL. 2014;21(1):28-35, España, 2014.

[24] Quaas Fermandois. Cecilia, Nuevos Enfoques en la Evaluación de los Aprendizajes, Revista Enfoques Educacionales Vol.2 ํo2 1999-2000 Departamento de Educación Facultad de Ciencias Sociales Universidad de Chile.

[25] Ortega Andrade NA, Romero Ramírez MA, Guzmán Saldaña RME, Rubrica para evaluar la elaboración de un Proyecto de Investigación Basado en el Desarrollo de Competencias, Universidad Autónoma del estado de Hidalgo, México. https://www.uaeh.edu.mx/scige/ boletin/icsa/n4/e6.html

[26] Bautista-Vallejo, José, Espigares, Manuel, Hernández-Carrera, Rafael, Aprendizaje Basado en Proyectos (ABP) ante el reto de una nueva enseñanza de las, Revista Brasileira de Ensino de Ciencia e Tecnología, Ponta Grossa, v. 10, n. 3, p. 43-60, set./dez. 2017. DOI: 10.3895/rbect.v10n3

[27] Sanmartí, N. y Márquez, C. (2017). Aprendizaje de las ciencias basado en proyectos: del contexto a la acción. Ápice. Revista de Educación Científica, 1(1), 3-16. DOI: https://doi.org/10.17979/arec.2017.1.1.2020. 